\section{LITERATURE REVIEW: WHY USE ROLEPLAY METHOD IN TEACHING SPEAKING?}

\author{
Irma Manda Negara \\ English Literature Study Program \\ Sekolah Tinggi Bahasa Asing Pontianak \\ Irmamanda23@gmail.com
}

Roleplay

method,

library

research,

teaching

speaking

\begin{abstract}
The roleplay method is one of the methods proven to improve students' speaking ability. This study aims to provide a more in-depth explanation of the use of the roleplay method in learning English to improve students' speaking skills. This research is a literature study by carrying out stages in the form of searching and finding relevant data, analyzing the data found, and expressing ideas from these findings. This study examines the understanding of the roleplay method, the procedure for implementing the roleplay method, and the impact of the roleplay method, especially in improving students' speaking skills. Based on the results, it was found that the roleplay method can improve students' speaking skills, increase selfconfidence, collaboration among students, and make the learning atmosphere fun and interesting.
\end{abstract}

Keywords: roleplay method, library research, teaching speaking

\title{
INTRODUCTION
}

Speaking skill is one component skills in English as a Foreign Language essential to master. This is similarly expressed by Richards (2008) and Bahadorfar \& Omidvar (2014) stated that speaking skill is a productive skill and become the main priority that must be mastered by students in the learning and teaching process of foreign languages. Furthermore, to master and develop speaking skills requires intense practice. It is based on a review of several studies that stated there are several difficulties in mastering these skills, including a lack of motivation, student interest, and teaching techniques (Akmal, 2018). Besides, some problems in the mastery of speaking skills, which include a lack of student motivation to practice, students anxiety, students confused what to say, and students afraid to make mistakes that lead to the emergence of a sense of inferiority to speak English (Krebt, 2017; Tahir \& Hanapi, 2017). Therefore, teachers

SPECTRAL Jurnal Ilmiah STBA Vol.7 No.1 Januari 2021 ISSN 0216-3381 must apply learning strategies to solve these problems. 
Roleplay

method,

library

research, teaching speaking

002

In the implementation of teaching speaking, to improve competence and mastery of speaking skills in terms of pronunciation, grammar, vocabulary, fluency, accuracy, and understanding, teachers need to implement appropriate learning strategies and methods (Tahir \& Hanapi, 2017; Rahayu, 2015). The use of a suitable method and strategy can improve student skills and competencies according to the expected outcome. As stated by Maulidar et al (2019) determine the success of the teaching process, it is important to implement appropriate learning strategies. Which, the strategy used must be able to attract the attention of students. Furthermore, the learning strategy is the first step in determining the application of appropriate methods, approaches, techniques and tactics to be used in managing the classroom in order to achieve successful language teaching and increase student learning achievement (Tahir, 2012).

There are several strategies, methods, and teaching techniques that can be implemented to improve students' speaking skills in English, in terms of the problems that have been described previously, one of which is Role-Play. As stated by Anjaniputra (2013) there are several speaking learning strategies, including "cooperative activities, role-playing, creative tasks, and drilling". Based on these, this study will explain the implementation of role-playing in speaking learning, based on several literature studies. The objective this study is to provide a more in-depth explanation of the application of role-playing in learning, as an effort to improve students' speaking skills.

\section{METHODS}

This study used library research, where this study conducted with several activities, are collecting information and data from various sources such as "reference books, previous similar research results, articles, notes, and journals relating to the problem to be resolved" (Sari, 2020). Further, this study was conducted by identifying and seeking information from relevant data, analyzing was findings, then developing and conveying ideas (Rasmuson, n.d.). This study examines literature related to the implementation of roleplay in the learning process to improve students' speaking skills. Furthermore, this study examines three necessary things, including explanation the meaning of the roleplay method, the roleplay method procedure in learning, and the impact of the roleplay method in learning especially to improve students' speaking skills. 
There are several definitions about the roleplay method according to the expert. First, the definition of the roleplay method according to Rayhan (2014) stated that this library method is an activity where students can express ideas, opinions, or feelings through words or articulation to others. Second, the definition of roleplay according to Rahayu speaking (2015) which describes roleplay as a technique that requires student interaction as role players and conducting discussions with members in role playing. Third, described by Harmer (2001), roleplay is a method that can be used to encourage students' proficiency in speaking. In practice, providing opportunities for students to express what they feel and think. Therefore, it is concluded that the roleplay method is a series of learning that can provide opportunities for students to build interaction, communication, cooperation, discussion, develop and express ideas to others, and train proficiency in speaking orally.

In the implementation, this role involves one or several members by providing a role that wants to convey, where this activity provides an opportunity in the form of interactive dialogue (Anggraeni, 2018; Gamanik et al., 2019). Implementation of roleplay divide students into groups, where all students are given the opportunity to express opinions and ideas on the tasks assigned by the teacher, then the student can act directly in the learning process, so that it can be regarded as an attempt to enhance the activity of students in speaking English, is a suitable and effective role to be carried out (Akmal, 2018). Thus, so far, it can be said that the roleplay method is an effective method to be applied in order to enhance the activity of students in the learning process and speak the English language, where students are given the opportunity to conduct an interactive dialogue as express opinions, ideas, thoughts, and solve problems according to the assigned task.

In its application, the students are divided into small groups to play a role, with the purpose of such engagement can improve students' ability to interact, especially orally. Cornet (1999) states that when students play role-playing, there will be an increase in fluency and oral interaction skills (cited in Krebt, 2017, p.864). Through this way, by providing opportunities for students to participate in role-playing, allowing students who rarely speak the English language, there will be an increased fluency. Because if it is well understood, by playing the role students can find out how other roles behave so that in 
Roleplay method, library research, teaching speaking

role-playing there are several aspects including "reactions, values, feelings, and attitudes" (Krebt, 2017). Finally, role-playing is an activity to develop speaking skills (Rayhan, 2014).

Roleplay is considered as a place that makes it easy for students to learn the basics of English conversation (Stocker, 2006 cited in Rayhan, 2014). By applying roleplay in teaching speaking, students get the opportunity to practice in terms of communication and roles in different social, as well as create and place themselves (Fadilah, 2016, p.210). Furthermore, Rahayu (2015) argued that roleplay helps students who are shy, who have difficulty in conversation by providing a mask, so they can improve their ability to speak and interact in any situation. Based on the exposure above, it is clear that roleplay method is a method applied in teaching speaking, to improve students' confidence and fluency in speaking, active learning, as well as dialogue and interaction with others.

\section{Roleplay procedure in learning}

Roleplay is an approach used in language teaching (Aliakbari \& Jamalvandi, 2010). There have been many studies that discuss the implementation of roleplay in learning, which is more predominantly carried out in language learning to improve students' speaking skills. Huda (2015) states that there are three reasons this method created, which refers to the assumption on authentic comparison to the problems in real life; this method can encourage to express and vent feelings; and involves several psychological aspects that include attitudes, values, and beliefs. In terms of the type, the implementation of roleplay divided into two forms, include 1) scripted, which is a script that comes from a dialogue book or text in the form of a speech, with this text script functioning as a means of conveying language meaning in a way that is easy to remember; 2) unscripted, in this case, the implementation of roleplay does not depend on a script or textbook. In this, students improvise. Further, students who define and develop the use of language and conversation content. Therefore, it requires preparation from both teachers and students (Byrne, 1986 cited in Suryani, 2015).

There are several studies that explain the procedures for implementing roleplaying, including those described by Susan House (cited in Fadilah, 2016), she mentions there are 4 procedures for implementing roleplay. The procedures include 1) students are 
accustomed to reading examples of dialogue; 2) dividing pairs A and B, giving dialogue and roles A and $\mathrm{B} ; 3$ ) give students play their role; 4) the teacher makes corrections and checks the students by changing roles, and repeats them. Added, according to Huang (cited in Rahayu, 2015) there are 6 main procedures in implementing roleplay, including: 1) the teacher must determine the teaching material in roleplay activities. Teachers can take teaching materials from various sources and select materials, as well as create their Roleplay method, library research, teaching speaking own authentic teaching materials. Interests of students, teaching objectives, and in determining the suitability of teaching materials; 2) choose the situation and make the dialogue, every situation created by the students themselves based on materials from the teacher; 3 ) before doing roleplay, the teacher teaches dialogue in role playing, the teacher needs to teach and ensure students use vocabulary, sentences, and dialogue, and provide opportunities for students to ask questions; 4) ask students to practice roleplay in pairs or small groups, then after they mastered their respective roles, ask them to exchange roles, and finally ask students to do a role play in front of the class; 5) ask students to modify the situation and dialogue from the original; 6) evaluate students' understanding related to vocabulary, sentences, and dialogues.

From the description above, it can be concluded that in implementing the roleplay method, it is necessary to consider procedures. Based on that, the writer tries to make a large outline of the procedures for implementing roleplay method are 1) the teacher must know the goals and objectives of implementing roleplay; 2) the teacher designs the implementation of roleplay learning; 3) the teacher prepares his authentic teaching materials to be adapted to the learning objectives, talents, interests and abilities of students; 4) the teacher designs a conversation concept in the form of dialogue by determining the situation; 5) The teacher conveys the conversation dialogue that has been made beforehand, then asks students to say it in the context of habituation and practising the students' pronunciation skills, as well as correcting and informing the accuracy of the pronunciation of vocabulary, sentences, and dialogue as a whole, in this case, the teacher must be able to ensure that students have mastered the aspects that must be mastered; 6) teachers divide students in groups or pairs, adapted to the learning design and the situation has been made before; 7) the teacher starts the roleplay activity by asking students to play their role correctly; 8) the teacher asks the students to switch roles if it is felt the students have mastered the previous roles, 9) students practice their role-play in front of the class, 
in front of his classmates, and teachers provide opportunities for students to develop basic research, teaching speaking dialogue; 10) the teacher conducting the evaluation.

It can be seen that in implementing this method, teachers have an important role in their activities, starting from planning to evaluation. Teachers must be able to choose the right strategy, stimulate students to be involved in learning, thinking, and communicating, because it can create effective teaching (Brown \& Atkins, 2002). In connection with the implementation of the method roleplay, teachers as facilitators, participants and evaluators. This is consistent with Liu \& Ding (2009) stated that the teacher acts as a facilitator who provides new language vocabulary that may be needed by students, the teacher feels the need to place himself as an involved participant and be part of his own role play, and the teacher as an audience, who observed the flow provide comments and suggestions at the end of the roleplay activity. Moreover, teachers can also be regarded as a "walking dictionary" which is ready to give a new vocabulary if necessary. In this case, it is necessary for the teacher to do this in order to help students learn new language structures that are easy to remember (Liu \& Ding, 2009).

\section{Impact of Implementing Role-play}

This study tries to make a conclusion and redescribe the impact of implementing roleplay based on several previous studies. Broadly, by implementing roleplay in English learning, it can provide stimulation for students to speak and improve students' speaking skills so that using the roleplay method is more effective than conventional methods (Mustadi, 2012; Alzboun et al., 2017; Setiawan, 2019; Abdullaeva et al., 2020). Then, by playing roles and exchanging roles, it can create an active and fun learning atmosphere for students to develop themselves, because it provides opportunities for students to be more creative in using language (Setiawan, 2019; Rahimy \& Safarpour, 2012; Arham et al., 2016). Furthermore, implementing roleplay can help the learning process, because it creates a learning environment and atmosphere that is "active, interactive, and constructive in practising the language, vocabulary, fluency, pronunciation and comprehension" (Rahayu, 2015; Alzboun et al., 2017). By creating a fun learning environment, the impact of increased attention of students to participate in learning, thus stimulating students to engage in learning activities roleplay (Rahimy \& Safarpour, 2012). It means can be said that creating a pleasant learning environment will have a positive impact on the development of skills, attention, and student participation. 
The above statement is also related to what is stated by Yohana et al., (2019) and Sunardi (2013) that the application of roleplay can build, improve and enrich students' vocabulary, where students are more able to imagine in language by building lots of vocabulary. Thus, based on this, there is an increase in students' speaking skills (Abdullaeva et al., 2020). Then, Mustadi (2012) found that the results of implementing roleplay provide real experiences as provisions before entering the workforce that research, teaching speaking increase self-confidence. By providing a real experience, it gives students memories that are easy to remember (Setiawan, 2019). It has been stated that the application of roleplay can stimulate student involvement so that it has an effect on improving student performance, where roleplay provides opportunities for students to develop their own conversations, as well as opportunities to be more creative in developing and expressing ideas. Of these, result in increased self-confidence and courage students to enrich their knowledge, attitudes, and skills (Sunardi, 2013) as well as increasing the motivation and activity of students, it can even minimize the passivity of students in participating in learning speaking (Rahayu, 2015).

Furthermore, with students being positively motivated to participate actively, even though they are still weak in their ability to speak English (Alzboun et al., 2017) a discussion forum can be created (Yohana et al., 2019). Then, the establishment of cooperative and collaborative fellow students because students are directly involved to play a role in learning activities (Setiawan, 2019). Therefore, with an increase in everything for students, it will lead to "increased student learning outcomes" (Setiawan, 2019). Based on all the descriptions above, the authors draw a core conclusion from the impact of implementing roleplay in learning and to improve students' speaking skills.

The following core conclusions of the elaboration of the impact of the roleplay methods in learning, especially learning English: 1) the creation of an active and fun learning environment because this method can be done inside and outside the classroom by raising several existing social situations; 2) increasing vocabulary, knowledge and vocabulary, so students are more free to develop the dialogue itself; 3) increase students' creativity in making a series of dialogues to play a role; 4) change students who are passive to be active to speak, even though they have weak speaking skills, because they are given the same opportunity to play roles and improvise the conversation; 5) creating cooperation and collaboration between students, because this method requires team / 
Roleplay method, library research, teaching speaking

008

group collaboration; 6) increasing the self-courage of students to appear; 7) increase motivation for students to develop existing knowledge and abilities; 8) increase student involvement in participating in the entire series of lessons; 9) increasing speaking skills of students; 10) improve student learning outcomes, and 11) enrich students' knowledge and skills. Based on the available evidence, it can be said that the roleplay method has a positive impact on students, reviewed from the aspect of increasing the knowledge and abilities, especially the ability to speak. Thus, it is quite important to apply this method in speaking learning in order to improve students' speaking skills.

\section{CONCLUSION}

By applying the strategies and appropriate learning methods can positively impact the development of student learning outcomes and achievement of learning objectives designed. Besides, it can solve the problem occurring in the implementation of learning. In learning English, speaking is one of the major problems experienced by students. It is because the English language is a second language for them. Based on some of the literature reviews and previous studies, proved that by applying the method of roleplay is one method that can solve the problem, especially in teaching speaking. Although it is not patented that this method is the greatest, compared to other methods. Therefore, the teacher as the principal mover in learning activities must be able to design a series of learning appropriately so that learning objectives and existing problems can be achieved and resolved, resulting in increased knowledge, skills, and learning outcomes for students.

\section{REFERENCES}

Abdullaeva, B., Tashtemirova, G., Dilnoza, S., Chorieva, D., \& Zarifova, Z. (2020). Developing Students' Speaking Skills through Role Play Technique. International Journal of Psychosocial Rehabilitation, 24(Special Issue 1), 805-810. https://doi.org/10.37200/ijpr/v24sp1/pr201221

Akmal. (2018). The Effect of Role-Play Method in English Speaking Skill. Journal of Science and Social Research, 1(1), 48-52. http://jurnal.goretanpena.com/index.php/JSSR Aliakbari, M., \& Jamalvandi, B. (2010). The Impact of "Role Play" on Fostering EFL 
Learners' Speaking Ability: A Task-Based Approach. Journal of Pan-Pacific Association of Applied Linguistics, 14(1), 15-29.

Alzboun, B., Smad, O. M., \& Baniabdelrahman, A. (2017). The Effect of Role Play Strategy on Jordanian EFL Tenth Grade Students' Speaking Skill. Arab World English Journal, 8(4), 121-136. https://doi.org/10.24093/awej/vol8no4.8

https://doi.org/10.23960/jpp.v8.i1.201804

Anjaniputra, A. G. (2013). Teacher's Strategies in Teaching Speaking To Students At

Secondary Level. Journal of English and Education, 1(2), 1-8.

Arham, R., Yassi, A. H., \& Arafah, B. (2016). The Use of Role Play to Improve

Teaching Speaking. INternational Journal of Scientific and Research Publication, 6(3), 239-241.

Bahadorfar, M., \& Omidvar, R. (2014). Technology in Teaching Speaking Skill. Acme International Journal of Multidisciplinary Research, 2(4), 9-13.

http://www.aijmr.net

Brown, G., \& Atkins, M. (2002). Effective Teaching In Higher Education. In Acta Universitatis Agriculturae et Silviculturae Mendelianae Brunensis (Vol. 53, Issue 9). Rouledge.

http://publications.lib.chalmers.se/records/fulltext/245180/245180.pdf\%0Ahttps://h dl.handle.net/20.500.12380/245180\%0Ahttp://dx.doi.org/10.1016/j.jsames.2011.03 .003\%0Ahttps://doi.org/10.1016/j.gr.2017.08.001\%0Ahttp://dx.doi.org/10.1016/j.p recamres. 2014.12

Fadilah. (2016). Teaching Speaking By Role-Play Activity. OKARA: Jurnal Bahasa Dan Sastra, 10(2), 209. https://doi.org/10.19105/ojbs.v10i2.980

Gamanik, N. M., Sanjaya, Y., \& Rusyati, L. (2019). Role-Play Simulation for Assessing Students' Creative Skill and Concept Mastery. Journal of Science Learning, 2(3), 71-78. https://doi.org/10.17509/jsl.v2i3.14848

Harmer, J. (2001). The Practice of English Language Teaching (Third Edit). Longman ELT. https://doi.org/10.1093/elt/57.4.401

Huda, K. (2015). PENINGKATAN KETERAMPILAN BERBICARA BAHASA INGGRIS MELALUI METODE ROLE PLAYING. Didaktikum: Jurnal Penelitian Tindakan Kelas, 16(3), 17-22.

Krebt, D. M. (2017). The Effectiveness of Role Play Techniques in Teaching Speaking for EFL College Students. Journal of Language Teaching and Research, 8(5), 863-870. https://doi.org/10.17507/jltr.0805.04

Liu, F., \& Ding, Y. (2009). Role-play in English Language Teaching. Asian Social Science, 5(10), 140-143. https://doi.org/10.5539/ass.v5n10p140

Maulidar, K., Gani, S. A., \& Samad, I. A. (2019). Teacher's Strategies in Teaching Speaking for Cadets. English Education Journal (EEJ), 10(1), 80-94.

Mustadi, A. (2012). Speaking Skill Improvement Melalui Role-Playing Pada Kompetensi English for Instruction di PGSD. Jurnal Didaktiva, 3(Januari), 1-16. 
Roleplay method, library research, teaching speaking

010

Rahayu, P. (2015). Role Play Strategy in Teaching Speaking. Jurnal Ilmiah Edu Research, 4(1), 61-70.

Rahimy, R., \& Safarpour, S. (2012). The Effect Of Using Role-Play On Iranian EFL Learners' Speaking Ability. Asian Journal of Social Sciences \& Humanities, 1(3), $50-59$.

Rasmuson, E. E. (n.d.). Library Research Process. Elmer E. Rasmuson Library. Retrieved August 28, 2020, from https://library.uaf.edu/ls101-researchprocess\#: :text=Library research involves the step,even change your topic completely.

Rayhan, J. M. (2014). The Impact of Using Role Play Techniques on Improving Pupils ' Speaking Skill for Primary School Ass . prof . Dr . Jassim Mohammed Rayhan Babylon University \College of Basic Education. Journal of Basic Education, 15, 516-530.

Richards, J. C. (2008). Teaching Listening and Speaking From Theory to Practice. In Language Teaching. Cambrige University Press. https://doi.org/10.1017/S0261444802211829

Sari, M. (2020). Penelitian Kepustakaan (Library Research) dalam Penelitian Pendidikan IPA. Natural Science: Jurnal Penelitian Bidang IPA Dan Pendidikan IPA, 6(1), 41-53.

https://ejournal.uinib.ac.id/jurnal/index.php/naturalscience/article/view/1555/1159

Setiawan, D. (2019). Penerapan Role Playing Untuk Meningkatkan Aktivitas Belajar dan Kemampuan Berbicara Bahasa Inggris. Jurnal Pendidikan Dasar, 2(2), 26-32. https://doi.org/10.30653/006.201922.24

Sunardi. (2013). Teaching Speaking Ability Through Role Play. Jurnal Pendidikan Dan Pembelajaran Khatulistiwa, 2(1), 1-14.

Suryani, L. (2015). The Effectiveness of Role Play in Teaching Speaking. ELTIN Journal, 3(II), 106-109.

Tahir, S. Z. Bin. (2012). Redefining Terms of Teaching and Learning Strategy, Method, Approach, Technique, and Model. November, 01st. https://www.academia.edu/12315177/REDEFINING_TERMS_OF_TEACHING_ AND_LEARNING_STRATEGY_METHOD_APPROACH_TECHNIQUE_AND MODEL

Tahir, S. Z. Bin, \& Hanapi. (2017). Lecturers' Method in Teaching Speaking at the University of Iqra Buru. International Journal of English Linguistics, 7(2), 73-80. https://doi.org/10.5539/ijel.v7n2p73

Yohana, F. M., Pratiwi, H. A., \& Susanti, K. (2019). Penerapan Metode Role Play Storytelling dengan Menggunakan Media Poster pada Kemampuan Berbahasa Inggris Mahasiswa Desain Komunikasi Visual. Magenta, STMK Trisakti, 3(01), 397-408. 